\title{
Isolation of Effective 3-Chlorobenzoate-Degraders in Soil Using Community Analyses by PCR-DGGE
}

\author{
Sho Morimoto ${ }^{*}$, Naoto Ogawa ${ }^{2}$, Akira Hasebe ${ }^{1}$, and TAKeshi FuJiI ${ }^{1}$ \\ ${ }^{1}$ National Institute for Agro-Environmental Sciences, 3-1-3 Kannondai, Tsukuba, Ibaraki 305-8604, Japan; and \\ ${ }^{2}$ Shizuoka University, Faculty of Agriculture, 836 Ohya, Suruga-ku, Shizuoka 422-8529, Japan
}

(Received June 30, 2008-Accepted July 21, 2008—Published online October 1, 2008)

\begin{abstract}
The screening of pollutant degraders by relying solely on cultivation techniques such as liquid enrichment often fails to isolate the actual degraders in the environment. Community analyses by PCR-denaturing gradient gel electrophoresis (DGGE) were performed to isolate bacteria that can degrade 3-chlorobenzoate (3CB) effectively in soil. A forest soil sample was repeatedly dosed with $3 \mathrm{CB}\left(500 \mathrm{mg} \mathrm{kg}^{-1}\right)$ to enrich it with indigenous 3CB-degraders, and changes in the bacterial community were monitored by PCR-DGGE of the $16 \mathrm{~S}$ rRNA gene and benzoate 1,2-dioxygenase alpha subunit gene (benA). Initially, it required about 3 weeks to degrade $3 \mathrm{CB}$ in the soil, whereas it took only 3 days after the third dose. With this accelerated degradation, several intensified bands appeared in the DGGE profiles of both $16 \mathrm{~S}$ rRNA gene and benA. We succeeded in isolating five 3CB-degrading Burkholderia strains corresponding to these bands by direct plating, while most of them were eliminated by liquid enrichment. Inoculation of the strains into the soil demonstrated that the five strains could degrade $3 \mathrm{CB}$ effectively in the soil. This study clearly shows significant bias during the liquid enrichment process and the advantage of using PCR-DGGE in screening effective degraders under environmental conditions.
\end{abstract}

Key words: PCR-DGGE, 3-chlorobenzoate degrading bacteria, soil, isolation

Discovering microorganisms capable of degrading target pollutants effectively is the most important step in bioremediation. To isolate such degraders, conventional cultivation techniques, typically liquid enrichment, have often been employed. This technique is a simple and efficient way to find target degraders in highly complex microbial communities in environmental samples. However, the degraders obtained by this method do not necessarily represent the actual degrader populations under environmental conditions, which are quite different from culture conditions ${ }^{7,39)}$. In other words, most degraders that function effectively under natural conditions would be overlooked if the screening strategy relied only on such culture methods.

In the past decade, "culture-independent methods" based on analyses of molecular markers such as 16S rRNA genes have been used extensively in the field of environmental microbiology $y^{1,26,36)}$. These methods enable one to understand microbial communities under natural conditions more directly without critical cultivation bias. PCR-denaturing gradient gel electrophoresis (DGGE) and PCR-temperature gradient gel electrophoresis (TGGE) are among the most established methods for molecular community profiling ${ }^{27)}$. Until now, the impacts of various pollutants on microbial communities in environmental samples have been studied by PCR-DGGE/TGGE, and many studies indicated changes in the community or dominance of certain members following pollution ${ }^{8,23,32,37)}$. Such observations are helpful to find key members involved in the degradation of pollutants under environmental conditions. However, to demonstrate the actual contribution of certain members found in the DGGE/

\footnotetext{
* Corresponding author. E-mail: shomo@niaes.affrc.go.jp; Tel: +8129-838-8309; Fax: +81-29-838-8309.
}

TGGE profiles, it is necessary to isolate them as substantial culture strains. In some studies, such key strains were isolated from relatively simple microbial communities by DGGE/TGGE profiling with culture methods ${ }^{18,34,38,39)}$. However, from highly complex communities such as those in soils, very few studies have succeeded in isolating such strains based on DGGE/TGGE profiles.

The main objective of this study is to isolate 3-chlorobenzoate (3CB)-degrading bacteria that can work effectively in soil, using a combination of PCR-DGGE and culture methods. Chlorobenzoates can be generated from the biodegradation of polychlorinated biphenyls ${ }^{11)}$, and $3 \mathrm{CB}$ has been most frequently used to study the bacterial degradation of this group of compounds. Up to now, 3CB-degrading bacteria have been isolated from environmental samples based on their 3CB-degrading ability in culture media ${ }^{4,6,12-16,20,29,31)}$, but there have been few attempts to isolate these degraders based on their ability in the environment. Previously, we showed that several Burkholderia-like bacteria became dominant in a forest soil after 3CB was added, by PCR-DGGE targeting the 16S rRNA gene and benzoate 1,2-dioxygenase alpha subunit gene $(\text { ben } A)^{25}$. This time we aimed to isolate such bacteria in order to demonstrate their contribution to the degradation of $3 \mathrm{CB}$ in soil. For this purpose, the soil was repeatedly dosed with $3 \mathrm{CB}$ to enrich it with indigenous $3 \mathrm{CB}$-degraders, and 3CB-degrading bacteria were collected from the soil by direct plating, which was expected to have less bias than liquid enrichment. In parallel, changes in the bacterial community following the 3CB treatments were monitored by PCRDGGE. Based on the DGGE profiles, the bacterial collection was screened to identify the enriched strains in the $3 \mathrm{CB}$ dosed soil. Finally, the strains identified as the enriched populations were inoculated into the soil to evaluate their 3CB- 
degrading ability in the soil.

\section{Materials and Methods}

Soil

Soil was obtained from the surface horizon of the conserved forest in the National Institute for Agro-Environmental Sciences, Tsukuba, Ibaraki prefecture. Before the experiments, the field-moist soil was passed through a $2-\mathrm{mm}$ sieve and pre-incubated at room temperature for 3 days to acclimatize the microbial communities to the experimental conditions. The physicochemical properties of the soil were described in our previous report ${ }^{25)}$.

\section{Accumulation of 3CB-degrading bacteria in the soil}

To concentrate the 3CB-degrading bacteria, $292.5 \mathrm{~g}$ of the soil was put into a glass jar ( $900 \mathrm{~mL}$ capacity) and mixed with $7.5 \mathrm{~g}$ of Celite $^{\circledR}$ (Wako Pure Chemical Industries, Osaka, Japan) that had absorbed $15 \mathrm{~mL}$ of $3 \mathrm{CB}$ stock solution $\left(10 \mathrm{mg} \mathrm{mL}^{-1}\right.$ in methanol), resulting in a final concentration of $500 \mathrm{mg} \mathrm{kg}^{-1} 3 \mathrm{CB}$ in the soil. Celite ${ }^{\circledR}$ was used to ensure even mixing of $3 \mathrm{CB}$ with the soil, and the methanol in the Celite ${ }^{\circledR}$ was completely evaporated before the mixing. The soil was incubated at $28^{\circ} \mathrm{C}$ for 38 days with a moisture content of $40 \%$. Soil subsamples were collected at days $0,7,14,21$, 28,35 , and 38 for the quantification of $3 \mathrm{CB}$ and extraction of DNA. Based on the consumption of $3 \mathrm{CB}$ during the incubation, additional $3 \mathrm{CB}\left(500 \mathrm{mg} \mathrm{kg}^{-1}\right)$ was added at days 21 and 35 . As controls, autoclaved soil (at $121^{\circ} \mathrm{C}$ for $1 \mathrm{~h}$ ) with $3 \mathrm{CB}$ (a single dose) and soil without $3 \mathrm{CB}$ were also prepared in the same manner as above.

\section{$H P L C$ analysis for quantification of $3 C B$}

Soil subsamples ( $2 \mathrm{~g}$ in triplicate) from each microcosm were suspended in $18 \mathrm{~mL}$ of $0.025 \mathrm{M} \mathrm{NaOH}$. The suspensions were subjected to sonication for $5 \mathrm{~min}$ and shaking on a horizontal shaker for $1 \mathrm{~h}$. The resulting slurry was centrifuged at $9,800 \times \mathrm{g}$ for 5 min. Then, the supernatant was filtered with a $0.2-\mu \mathrm{m}$ pore-size membrane filter and subjected to HPLC using an HP1100 system (Agilent Technologies, Palo Alto, CA, USA) with an XDB-C18 column (Agilent Technologies). The mobile phase was an isocratic mixture of acetonitrile: $0.1 \% \mathrm{H}_{3} \mathrm{PO}_{4}(1: 1, \mathrm{v} / \mathrm{v})$ delivered at a flow rate of $1 \mathrm{~mL} \mathrm{~min}{ }^{-1}$. The column temperature was held constant at $36^{\circ} \mathrm{C}$, and the absorption was measured at a wavelength of $200 \mathrm{~nm}$.

\section{Media}

Soil extract agar was prepared as follows. The forest soil mixed with distilled water (five times the weight of soil) was autoclaved at $121^{\circ} \mathrm{C}$ for $20 \mathrm{~min}$ and left overnight for the soil particles to precipitate. The supernatant was filtered using filter paper No. 131 (Toyo Roshi Co. Ltd., Tokyo, Japan) and adjusted to $\mathrm{pH} 6.8$ with $\mathrm{KOH}$ solution. To make the agar medium, $\mathrm{K}_{2} \mathrm{HPO}_{4}$ and Bacto-Agar (Difco Lab., Detroit, MI, USA) at a final concentration of $0.02 \%$ and $2 \%$, respectively, were added to the extract. After autoclaving at $121^{\circ} \mathrm{C}$ for $20 \mathrm{~min}$, the medium was supplemented with the filtersterilized $3 \mathrm{CB}$ stock solution $(100 \times$ concentrated and neutralized with $\mathrm{NaOH}$ ) to a final concentration of $500 \mathrm{mg} \mathrm{L}^{-1}$.

The basal salts medium ${ }^{29)}$ consisted of the following components (per liter of distilled water): $\left(\mathrm{NH}_{4}\right)_{2} \mathrm{SO}_{4}, 1.1 \mathrm{~g} ; \mathrm{K}_{2} \mathrm{HPO}_{4}, 2.29 \mathrm{~g}$; $\mathrm{KH}_{2} \mathrm{PO}_{4}, 0.9 \mathrm{~g} ; \mathrm{MgSO}_{4} \cdot 7 \mathrm{H}_{2} \mathrm{O}, 0.1 \mathrm{~g} ; \mathrm{MnSO}_{4} \cdot 4-6 \mathrm{H}_{2} \mathrm{O} ; 0.025 \mathrm{~g}$; $\mathrm{FeSO}_{4} \cdot 7 \mathrm{H}_{2} \mathrm{O}, 0.005 \mathrm{~g}$; and L-ascorbic acid, $0.005 \mathrm{~g}$. As a sole carbon source, $3 \mathrm{CB}$ was added to the medium to a final concentration of $500 \mathrm{mg} \mathrm{L}^{-1}$ as described above. For preparing the agar plates, 2\% purified agar (Difco) was added to the medium.

\section{Isolation of bacteria from the $3 C B$-dosed soil}

Direct plating on the soil extract agar (see Media) was used to isolate bacteria from the 3CB-dosed soil. We sampled $5 \mathrm{~g}$ of the soil after 38 days and made a 10 -fold dilution series with $10 \mathrm{mM}$ sodium phosphate buffer ( $\mathrm{pH}$ 6.8). Triplicate soil extract agar plates were inoculated with $100 \mu \mathrm{L}$ from each of the $10^{-5}$ and $10^{-6}$ dilutions and incubated at $28^{\circ} \mathrm{C}$ for 10 days. The resulting single colonies were picked at random and transferred onto new plates to ensure their purity.

Liquid enrichment was also used. Triplicate flasks containing 99 $\mathrm{mL}$ of the basal salts medium (see Media) were inoculated with $1 \mathrm{~g}$ of the 3CB-dosed soil and incubated with rotary shaking (180 rpm, $28^{\circ} \mathrm{C}$ ). After the first incubation for 2 days, $1 \mathrm{~mL}$ of culture taken from each flask was transferred to $99 \mathrm{~mL}$ of the new medium and incubated for a further 2 days. After the second incubation, $0.5 \mathrm{~mL}$ of the culture was serially diluted with the sodium phosphate buffer. Bacterial isolates were collected from the dilutions by plating on the soil extract agar as described above. During the liquid enrichment, a small portion from each culture was sampled to extract DNA for PCR-DGGE.

The isolates obtained by these methods were incubated on $\mathrm{R} 2 \mathrm{~A}$ agar (Difco) supplemented with $500 \mathrm{mg} \mathrm{L}^{-1}$ of $3 \mathrm{CB}$ at $28^{\circ} \mathrm{C}$ for 4 days. After the incubation, the bacterial cells were collected from the plates for DNA extraction (see DNA extraction). In addition, the isolates were inoculated onto the basal salts agar (see Media) to briefly examine their ability to utilize $3 \mathrm{CB}$.

\section{DNA extraction}

For PCR-DGGE of the soil microcosms, DNA was extracted from $0.4 \mathrm{~g}$ of duplicate soil subsamples using a FastDNA ${ }^{\circledR}$ spin kit for soil (Qbiogene, Inc., Irvine, CA, USA) and FastPrep ${ }^{\circledR}$ instrument (Qbiogene), for $30 \mathrm{sec}$ at a speed setting of 5.5. To improve DNA recovery efficiency, $16 \mathrm{mg}$ of skim milk (Difco) was added to $978 \mu \mathrm{L}$ of sodium phosphate buffer (included in the kit) before $0.4 \mathrm{~g}$ of soil was suspended in the buffer ${ }^{17}$. Further procedures followed the manufacturer's instructions, and DNA was eluted using $80 \mu \mathrm{L}$ of the DNA elution buffer included in the kit. To remove the remaining humic substances from the DNA solution, the samples were further purified using a DNA Clean \& Concentrator ${ }^{\mathrm{TM}}-25$ (Zymo Research Corp., Orange, CA, USA). DNA extraction from the liquid enrichment culture was performed using a standard miniprep procedure ${ }^{40)}$. DNA extraction from the bacterial isolates was performed using a Puregene DNA Isolation Kit (Gentra Systems, Inc. Minneapolis, MN, USA) according to the instruction manual.

\section{PCR conditions}

All PCR amplifications were performed in an iCycler ${ }^{\mathrm{TM}}$ (BioRad Laboratories, Hercules, CA, USA) with KOD-Plus (Toyobo, Osaka, Japan) DNA polymerase. Two primer sets were used for PCR-DGGE of bacterial communities in the soil and liquid enrichment cultures. The same sets were also used for the analyses of bacterial isolates.

The first set targeting the V3-V5 region of bacterial 16S rRNA genes consisted of GC338f (5'-ACTCCTACGGGAGGCAGCAG3', attached with a GC clamp) ${ }^{30)}$ and 907r (5'-CCGTCAATTCCTTTRAGTTT-3' $)^{21)}$. The PCR mixtures contained $5 \mu \mathrm{L}$ of $10 \times$ PCR buffer for KOD-Plus, $0.2 \mathrm{mM}$ of each dNTP, $1.5 \mathrm{mM}$ of $\mathrm{MgSO}_{4}, 1 \mu \mathrm{L}$ of dimethyl sulfoxide (DMSO), $0.2 \mu \mathrm{M}$ of each primer, $1.0 \mathrm{U}$ of KOD-Plus DNA polymerase, and $1 \mu \mathrm{L}$ of DNA template (ca. 100 to $200 \mathrm{ng}$ ) in a total volume of $50 \mu \mathrm{L}$. The reaction conditions were as follows: initially $94^{\circ} \mathrm{C}$ for $2 \mathrm{~min} ; 35$ cycles of $30 \mathrm{sec}$ each at $94^{\circ} \mathrm{C}, 50^{\circ} \mathrm{C}$, and $68^{\circ} \mathrm{C}$; and finally $68^{\circ} \mathrm{C}$ for $1 \mathrm{~min}$.

The second set consisted of semi-nested primers designed from the conserved regions of the genes encoding the alpha subunit of benzoate 1,2-dioxygenase (benA) derived from various known isolates. The primers were described in detail in our previous report ${ }^{25}$. The first PCR mixtures consisted of the same composition as those for the PCR of 16S rRNA genes but with the primers, BAF1 (5'CGTTYCAYGGCTGGACVTTC-3') and BAR1 (5'-CGGAAYTCYTCSAGRTCGTC-3'). The conditions for the first PCR were as follows: initially $94^{\circ} \mathrm{C}$ for $2 \mathrm{~min} ; 30$ cycles of $30 \mathrm{sec}$ each at $94^{\circ} \mathrm{C}$, $54^{\circ} \mathrm{C}$, and $68^{\circ} \mathrm{C}$; and finally $68^{\circ} \mathrm{C}$ for $1 \mathrm{~min}$. In the second PCR, 0.5 $\mu \mathrm{L}$ of the first PCR product was transferred to the second reaction mixture containing the same constituents as the first but with the primers, BAF1-GC (BAF1 with a GC clamp attached to the 5' end) and BAR2 (5'-GTCGCGGCGTAGTTCCAGTG-3'). The second 
PCR was performed as follows: initially $94^{\circ} \mathrm{C}$ for $2 \mathrm{~min} ; 20$ cycles of $30 \mathrm{sec}$ each at $94^{\circ} \mathrm{C}, 56^{\circ} \mathrm{C}$, and $68^{\circ} \mathrm{C}$; and finally $68^{\circ} \mathrm{C}$ for $1 \mathrm{~min}$.

All PCR products were electrophoresed on a 1.0\% agarose gel to ascertain that they exhibited sizes close to what was expected: approximately $630 \mathrm{bp}(16 \mathrm{~S})$ and $398 \mathrm{bp}($ benA). The products were purified using a PCR Clean-Up ${ }^{\mathrm{TM}}$ Kit (MO BIO Laboratories, Solana Beach, CA, USA).

\section{$D G G E$ analyses}

DGGE was performed using a D-Code universal mutation detection system (Bio-Rad Laboratories), according to the instruction manual. The conditions for separation of the 16S rRNA gene fragments and benA fragments were as follows: running at $65 \mathrm{~V}$ for $21 \mathrm{~h}$ in a $6 \%$ polyacrylamide gel with the denaturing gradient from $45 \%$ to $65 \%$ at $60^{\circ} \mathrm{C}$, and running at $60 \mathrm{~V}$ for $24 \mathrm{~h}$ in a $10 \%$ polyacrylamide gel with the denaturing gradient from $55 \%$ to $70 \%$ at $60^{\circ} \mathrm{C}$, respectively. In both analyses, about $200 \mathrm{ng}$ of each PCR product was loaded per lane. After electrophoresis, gels were stained with SYBR ${ }^{\circledR}$ Green I nucleic acid gel stain (Molecular Probes, Leiden, The Netherlands), and the bands were visualized with a Molecular Imager FX (Bio-Rad Laboratories). Bands of interest were excised for DNA sequencing. Each excised band was washed twice with 1 $\mathrm{mL}$ of distilled water. A small chip (less than $1 \mathrm{~mm}^{3}$ ) of each piece was used as a template for PCR to recover the DNA fragments. Conditions were the same as those for the original PCR (see above) except that the initial denaturing step was extended to $5 \mathrm{~min}$ and the number of cycles was changed to 28-40 based on the intensity of each band. The DNA fragments were subjected to DGGE again to confirm their purity and identity. The confirmed fragments were used as templates for direct sequencing. When it was difficult to make a target band homogeneous, the fragments were cloned using a PCR-Script ${ }^{\mathrm{TM}}$ Amp cloning kit (Stratagene, La Jolla, CA, USA). The clone containing the target fragment was screened by DGGE and then sequenced.

\section{DNA sequencing and phylogenetic analyses}

DNA sequencing reactions were performed using a BigDye ${ }^{\mathrm{TM}}$ Terminator v3.1 (Applied Biosystems, Foster City, CA, USA). The reaction products were analyzed with an ABI PRISM ${ }^{\circledR} 3100$ Genetic Analyzer (Applied Biosystems). The phylogenetic analyses, including a BLAST search of the GenBank database and construction of neighbor-joining trees, were performed using the MEGA 3.1 program (available at URL: http://www.megasoftware.net).

\section{Inoculation of bacteria into soil}

Bacterial isolates having the same $16 \mathrm{~S}$ rRNA gene or benA as the intensified DGGE bands were selected based on the nucleotide sequences obtained from each isolate and band. To evaluate their ability to degrade $3 \mathrm{CB}$ in the soil, the selected isolates were inoculated independently or together into the 3CB-dosed soil, which was newly prepared for this inoculation experiment as follows. The forest soil sample was divided into glass bottles $(450 \mathrm{~mL}$ capacity), each containing $92.5 \mathrm{~g}$. Each soil was mixed with $2.5 \mathrm{~g}$ of $3 \mathrm{CB}-\mathrm{con}-$ taining Celite ${ }^{\mathbb{R}}$ (see Experimental design) to a final concentration of $500 \mathrm{mg} \mathrm{kg}^{-1} 3 \mathrm{CB}$, and then inoculated with $5 \mathrm{~mL}$ of bacterial cell suspension. The cell suspension was prepared as follows. Each selected isolate was incubated overnight at $28^{\circ} \mathrm{C}$ in 10 -fold diluted tryptic soy broth (Difco) containing $500 \mathrm{mg} \mathrm{L}^{-1} 3 \mathrm{CB}$, with rotary shaking at $180 \mathrm{rpm}$. Cells were collected from the culture by centrifugation, washed with $10 \mathrm{mM}$ sodium phosphate buffer ( $\mathrm{pH}$ 6.8), and resuspended in the sodium phosphate buffer at a concentration of $\mathrm{OD}_{600}=0.4$ (corresponding to a cell density of ca. $10^{8}-10^{9}$ cells $\mathrm{mL}^{-1}$ ). When several isolates were inoculated together, the same volume of each cell suspension was mixed and $5 \mathrm{~mL}$ of the mixture was used as an inoculum. After the inoculation, the soils were incubated for 14 days at $28^{\circ} \mathrm{C}$ with a moisture content of $40 \%$. During the incubation, triplicate subsamples were collected temporally from each soil and subjected to the quantification of $3 \mathrm{CB}$ and extraction of DNA, as described above.

\section{Nucleotide sequence accession numbers}

The sequences obtained in this study have been deposited in the DNA Data Bank of Japan (DDBJ) under accession numbers AB303625 to AB303643.

\section{Results}

\section{Degradation of $3 C B$ in the soil}

The concentration of $3 \mathrm{CB}$ in the soil decreased to less than $3 \%$ of the initial value after 3 weeks of incubation (Fig. 1). This decrease was because of indigenous degraders, because it was not observed in the autoclaved soil. Moreover, the rate of decrease was accelerated by repeated addition of $3 \mathrm{CB}$. That is, it took only 3 days to degrade $500 \mathrm{mg} \mathrm{kg}^{-1} 3 \mathrm{CB}$ after the third dose. These results suggest that indigenous $3 \mathrm{CB}-$ degraders were made more abundant in the forest soil by repeated doses of $3 \mathrm{CB}$.

\section{PCR-DGGE analyses}

There was no change in the DGGE profiles of the soil without $3 \mathrm{CB}$ throughout the incubation period (only the profiles of day 0 and 38 are shown in Fig. 2). However, for the soil dosed with $3 \mathrm{CB}$, the profiles of both $16 \mathrm{~S}$ rRNA gene and benA clearly showed that several bands were intensified. There were differences in when each band intensified. For example, bands $\mathrm{Sr} 1,2$, and 3 intensified at day 7 in the profiles of 16S rRNA gene, whereas bands Sr5, 6, and 7 intensified after the second dose at day 21. Similarly, band Sb1 intensified more quickly than other bands (Sb2, 3, 4, and 5) in the profiles of benA.

The DGGE profiles of liquid enrichment cultures showed very similar patterns in the triplicate batches; therefore, only the profiles derived from one of the batches are shown in Fig. 2. The profiles of both $16 \mathrm{~S}$ rRNA gene and benA indicated that one of the intensified bands (Sr6 and Sb4, respectively) in the profiles of the $3 \mathrm{CB}$-dosed soil was particularly strong in the liquid enrichment culture ( $\operatorname{Lr} 5$ and Lb2, respectively). In other words, most of the intensified bands in the profiles of the 3CB-dosed soil were eliminated during the process of liquid enrichment. For example, bands $\mathrm{Sr} 1, \mathrm{Sr} 3$, and $\mathrm{Sr} 4$ in the profile of $16 \mathrm{~S}$ rRNA gene, and $\mathrm{Sb} 1, \mathrm{Sb} 2$, and $\mathrm{Sb} 5$ in that of benA disappeared from the profiles of the liquid enrich-

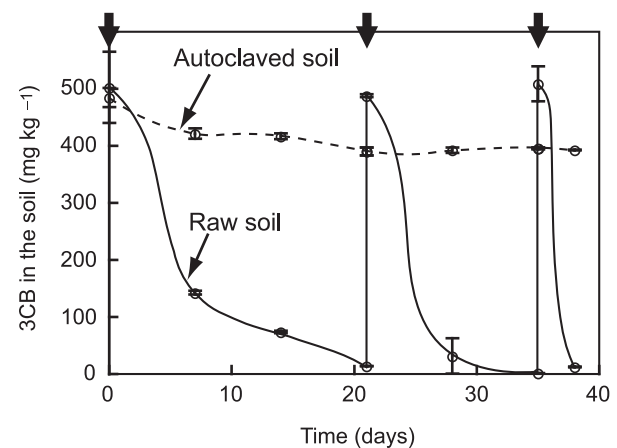

Fig. 1. Degradation of $3 \mathrm{CB}$ in raw soil and autoclaved soil. Bold arrows indicate when the $3 \mathrm{CB}$ was added, but the second and third arrows are only for raw soil. Error bars represent the standard deviation of triplicate determinations. 

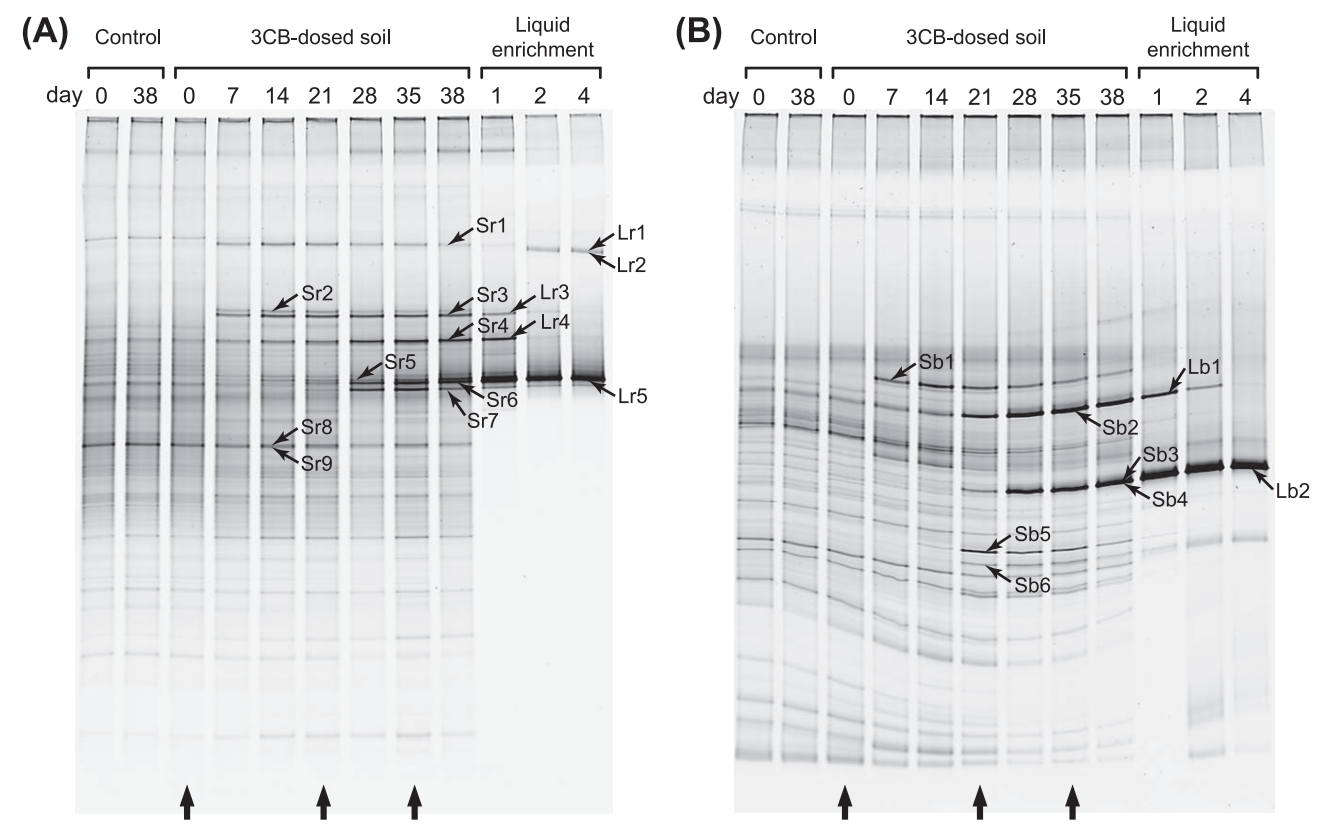

Fig. 2. DGGE profiles of PCR-amplified 16S rRNA gene fragments (A) and benA fragments (B) from soil and liquid enrichment cultures. Control is the soil without $3 \mathrm{CB}$. Liquid enrichment culture was inoculated with the 3CB-dosed soil collected at day 38 . Bold arrows indicate when the $3 \mathrm{CB}$ was added. Sequenced bands were named and indicated with arrows in the profiles. The bands having identical sequences were as follows: Sr3 and Lr3; Sr4 and Lr4; Sr6 and Lr5; Sb2 and Lb1; Sb4 and Lb2.

ment culture at day 4 . We sequenced DGGE bands indicated by arrows in Fig. 2 for further analyses.

\section{Isolation of bacteria from the $3 C B$-dosed soil}

In total, 31 isolates were picked from hundreds of colonies obtained from the 3CB-dosed soil by direct plating or liquid enrichment. Partial fragments of the 16S rRNA gene and benA were amplified from each isolate using the same primers as those for the PCR-DGGE analyses, and then the nucleotide sequences of the fragments were determined for comparison with the sequences of the DGGE bands shown in Fig. 2. It was found that 28 of the 31 isolates had the same $16 \mathrm{~S}$ rRNA or benA sequences as those of the DGGE bands. We grouped these 28 isolates into six strains based on their $16 \mathrm{~S}$ rRNA and benA sequences. The six strains and their corresponding DGGE bands are shown in Table 1.

One of the strains, ASS7, was isolated with high frequency by both direct plating and liquid enrichment. This was consistent with the finding that the DGGE bands ( $\mathrm{Sr} 6$ and $\mathrm{Lr} 5$ in the profiles of the 16S rRNA gene, and $\mathrm{Sb} 4$ and Lb2 in the profiles of benA) corresponding to ASS7 were prominent in the profiles of both the soil and the liquid enrichment culture. The bands corresponding to ASS7 ( $\mathrm{Sr} 6, \mathrm{Lr} 5, \mathrm{Sb} 4$, and Lb2) nearly overlapped with the bands corresponding to ASS11 ( $\mathrm{Sr} 5$ and $\mathrm{Sb} 3$ ). Although these bands looked to be single bands in the profiles of both 16S rRNA gene and benA, direct sequencing and cloning revealed that they were derived from the two strains (ASS7 and ASS11), and mainly from ASS7 especially in the liquid enrichment profiles. Strains ASS3, 8, 11 , and 14 had the same sequences as those of the DGGE bands that intensified in the profiles of the 3CB-dosed soil but declined in those of the liquid enrichment culture. Although strain ASS8 presented an intensified band (Sr3) in the profile of $16 \mathrm{~S}$ rRNA gene, we could not identify the band corresponding to this strain in the profile of benA. However, it was deduced that a faint band between $\mathrm{Sb} 2$ and $\mathrm{Sb} 3$ corresponded to strain ASS8 because the benA fragments amplified from this strain formed a band at the position in the profile of benA (data not shown). The five strains mentioned above could grow on the basal salt agar containing $3 \mathrm{CB}$ as a sole carbon source.

Strain ASLS14 isolated from the liquid enrichment culture had the same 16S rRNA sequence as that of band Lr2, which appeared only in the profile of the liquid enrichment culture. Although we determined the ben $A$ sequence of the strain using the PCR product amplified from its genomic DNA, we could not identify the band corresponding to this strain in the profile of benA. This strain could not grow on the basal salt agar containing $3 \mathrm{CB}$.

\section{Phylogenetic analyses}

Neighbor-joining trees were constructed using partial nucleotide sequences of 16S rRNA gene or benA derived from the above-mentioned strains and DGGE bands, and those obtained from GenBank (Figs. 3 and 4).

The tree of 16S rRNA genes showed that all strains and bands with two exceptions (bands Sr8 and Sr9) belonged to the family Burkholderiaceae. In particular, all the bands intensified in the 3CB-dosed soil belonged to the cluster of Burkholderia spp. Strain ASS14, which appeared as intensified bands in the profiles of 3CB-dosed soil but disappeared from those of liquid enrichment culture, was closely related to an uncultured bacterium $\mathrm{MeBr} 20$, which had been found in a soil treated with methyl bromide ${ }^{24}$. Strains ASS3, 7, and 11 , corresponding to bands $\mathrm{Sr} 7,6$, and 5 , respectively, were genetically similar to each other. Strain ASS7 formed prominent bands in the profiles of both the soil and liquid enrichment culture and was most closely related to Burkholderia 
Table 1. Bacterial strains and their corresponding DGGE bands

\begin{tabular}{|c|c|c|c|c|c|c|}
\hline \multirow{2}{*}{ Strain } & \multirow{2}{*}{ Genus $^{\mathrm{a}}$} & \multicolumn{2}{|c|}{ Corresponding DGGE band } & \multirow{2}{*}{ 3CB utilization ${ }^{\mathrm{b}}$} & \multicolumn{2}{|c|}{ Number of homologus isolates } \\
\hline & & 16S rRNA gene & benA & & Direct plating $^{\mathrm{c}}$ & Liquid enrichment ${ }^{\mathrm{d}}$ \\
\hline ASS3 & Burkholderia sp. & $\mathrm{Sr} 7$ & Sb6 & + & 7 & 1 \\
\hline ASS7 & Burkholderia sp. & Sr6, Lr5 & $\mathrm{Sb} 4, \mathrm{Lb} 2$ & + & 6 & 6 \\
\hline ASS8 & Burkholderia sp. & $\mathrm{Sr} 3, \mathrm{Lr} 3$ & not identified & + & 3 & \\
\hline ASS11 & Burkholderia sp. & Sr5 & Sb3 & + & 2 & \\
\hline ASS14 & Burkholderia sp. & $\mathrm{Sr} 4, \mathrm{Lr} 4$ & $\mathrm{Sb} 2, \mathrm{Lb} 1$ & + & 2 & \\
\hline ASLS14 & Ralstonia sp. & $\operatorname{Lr} 2$ & not identified & - & & 1 \\
\hline
\end{tabular}

${ }^{a}$ Classified according to the $16 \mathrm{~S}$ rRNA gene phylogeny. ${ }^{\mathrm{b}}$ Judged based on growth on the basal salts agar plate containing $3 \mathrm{CB}$ as a sole carbon source. ${ }^{\mathrm{c}}$ Isolated by direct plating from the 3CB-dosed soil. ${ }^{\mathrm{d}}$ Isolated by liquid enrichment culture.

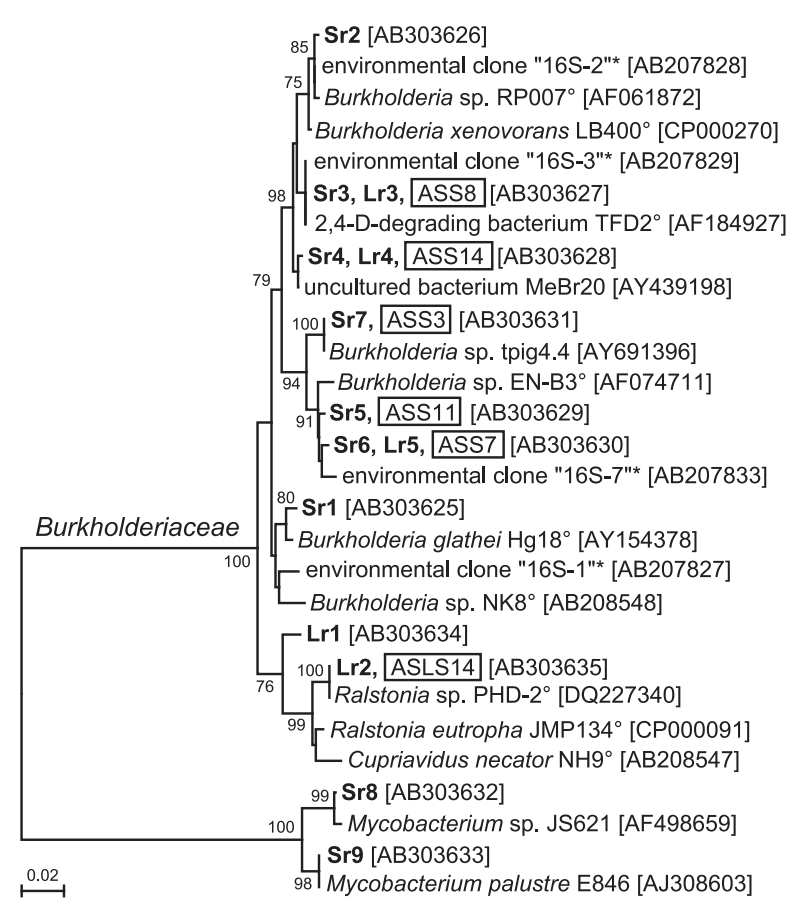

Fig. 3. Neighbor-joining tree showing phylogeny of partial sequences (about $548 \mathrm{bp}$ ) of 16S rRNA gene derived from DGGE bands and isolated strains. The DGGE bands are represented in bold, and the strains isolated in this study are shown in square boxes. The accession number for each sequence is enclosed in brackets. The clones labeled with an asterisk have been found in our previous study as DGGE bands that intensified in the soil after a single dose of $3 \mathrm{CB}$. The isolates labeled with $\mathrm{a}^{\circ}$ have been reported in other studies to be degraders of aromatic compounds. Bootstrap values above $70 \%$ are shown.

sp. EN-B3 (97\% homology), which had been obtained from a 3CB-enrichment culture with a peat-forest soil in the Netherlands ${ }^{32}$. Strain ASS8, corresponding to band Sr3, had the same 16S rRNA sequence as a 2,4-D-degrading bacterium, TFD2 ${ }^{35)}$, and an environmental clone, 16S-3, which had been obtained from the $3 \mathrm{CB}$-dosed soil in our previous study $^{25)}$. Strain ASLS14, corresponding to band Lr2, had the same 16S rRNA sequence as a phenol degrader, Ralstonia sp. PHD2.

The tree of benA showed that all of the genes of our strains were closely related to those of Burkholderiaceae, and this was consistent with the findings from the tree of 16S rRNA genes. Although the strain corresponding to band Sb5 was not isolated, the tree indicated that this band was also derived from a Burkholderia sp. closely related to strains ASS3, 7,

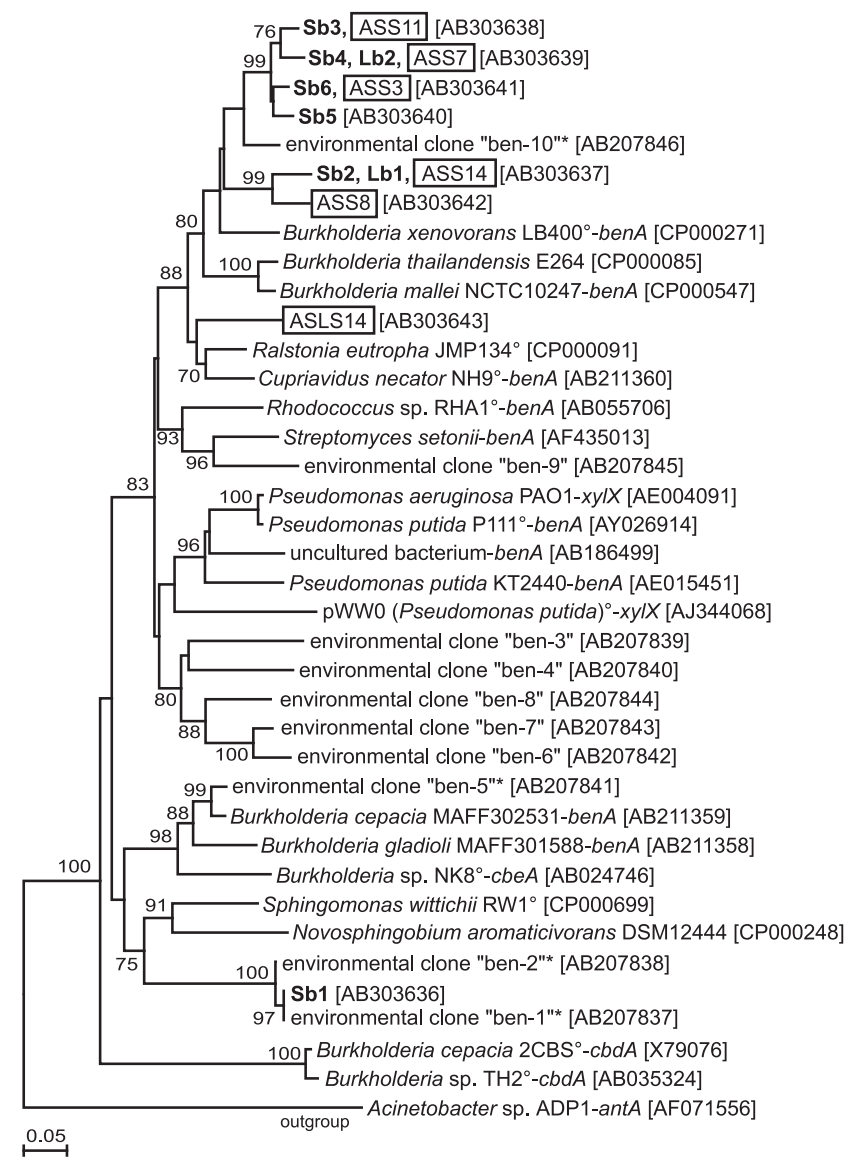

Fig. 4. Neighbor-joining tree showing phylogeny of partial sequences (318 bp) of the benzoate 1,2-dioxygenase alpha-subunit gene (benA) derived from DGGE bands and isolated strains. The DGGE bands are represented in bold, and the strains isolated in this study are shown in square boxes. The accession number for each sequence is enclosed in brackets. The clones labeled with an asterisk have been found in our previous study as DGGE bands that intensified in the soil after a single dose of $3 \mathrm{CB}$. The isolates labeled with $\mathrm{a}^{\circ}$ have been reported in other studies to be degraders of aromatic compounds. The tree is rooted with the anthranilate dioxygenase large-subunit gene (antA) from Acinetobacter sp. ADP1. Bootstrap values above $70 \%$ are shown.

and 11. Band Sb1 was identical to the environmental clone ben-1, which had been obtained from the 3CB-dosed soil in our previous study ${ }^{25}$. The tree suggested that this band had a quite different origin from those of the other intensified bands. 


\section{CB-degrading ability of the strains in soil}

The bacterial strains listed in Table 1 were inoculated into the soil with $3 \mathrm{CB}$ to evaluate their 3CB-degrading ability in the soil. The degradation of $3 \mathrm{CB}$ was clearly accelerated in all soils inoculated with each of the five Burkholderia strains (ASS3, 7, 8, 11, and 14) in comparison with that in the raw soil without inoculation (Fig. 5a-e). In addition, the DGGE profiles of each soil indicated that these strains quickly adapted to the soil after the inoculation. Co-inoculation of the five strains increased the rate of degradation in the soil to the same extent as the independent inoculations (Fig. 5f).

No acceleration of $3 \mathrm{CB}$ degradation was observed in the soil inoculated with strain ASLS14 corresponding to band Lr2, which had appeared only in the profiles of the liquid enrichment culture. The DGGE profile of the soil suggested that this strain could not adapt to the soil (Fig. 5g). From these findings, and also that this strain could not grow on the basal salts agar containing $3 \mathrm{CB}$, we concluded the strain did not relate to the degradation of $3 \mathrm{CB}$ in the soil.

Based on above results, we concluded that the five Bulkhoderia strains (ASS3, 7, 8, 11, and 14) were effective 3CB-degraders in soil.

\section{Discussion}

In this study, we succeeded in isolating five Burkholderia strains that could effectively degrade $3 \mathrm{CB}$ in soil using a combination of culture methods and PCR-DGGE. Although a few interesting bands (e.g., Sr1 and Sb1), which did not correspond to any of our isolates, remained in the DGGE profiles, bands corresponding to the five Burkholderia strains (ASS3, 7, 8, 11, and 14) comprised most of the prominent bands that intensified following the repeated application of $3 \mathrm{CB}$. Therefore, these strains likely represent key members comprising the $3 \mathrm{CB}$-degrading populations in the (a)

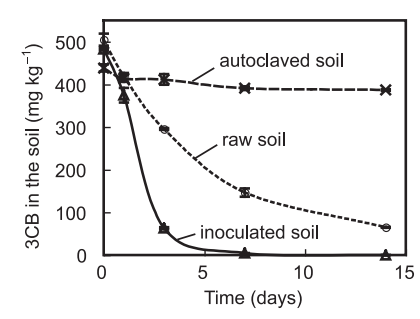

(c)

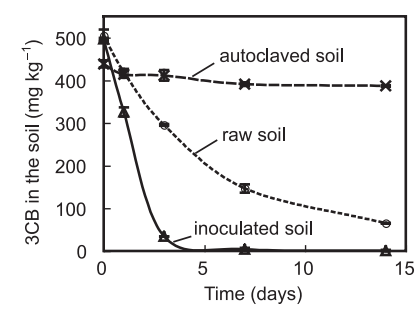

(e)

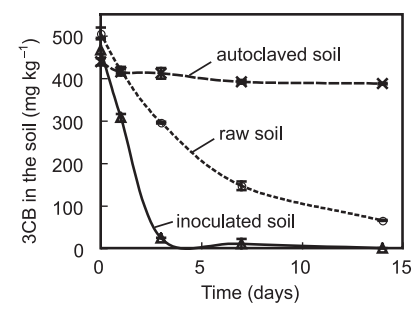

(g)

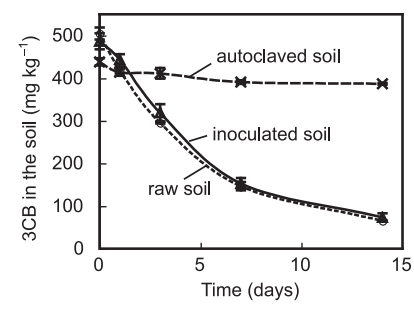

day
$0 \quad 3$

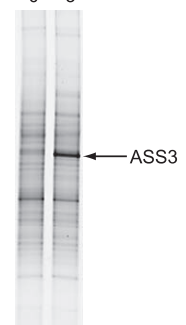

day

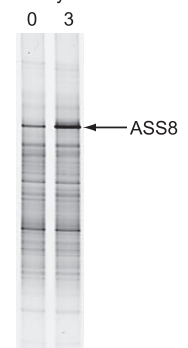

$0_{0}^{\text {day }} 3$

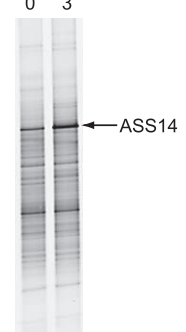

day

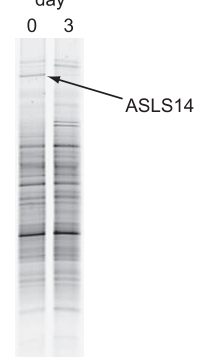

(b)

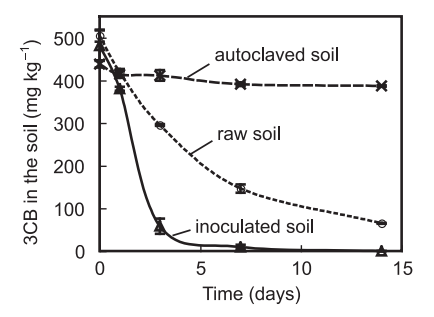

(d)

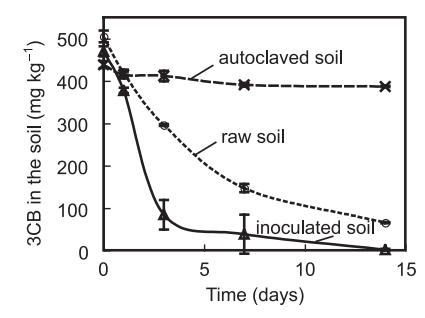

(f)
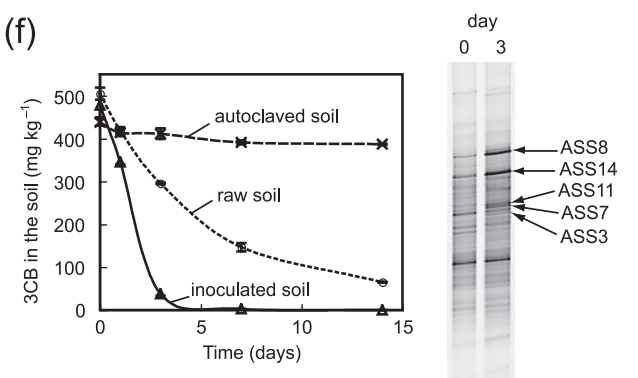

Fig. 5. Effects of isolated strains on $3 \mathrm{CB}$ degradation in soil. Figure (a), inoculated with ASS3; (b), ASS7; (c), ASS8; (d), ASS11; (e), ASS14; (f), coinoculated with the preceding five strains; (g), inoculated with ASLS14. Each DGGE profile consists of 16S rRNA gene fragments amplified from the soil immediately after the inoculation and after 3 days. The DGGE bands corresponding to the inoculated strains are indicated with arrows. Error bars represent the standard deviation of triplicate determinations. 
soil. Although 3CB-degrading Burkholderia spp. have been isolated from various soils ${ }^{12,14,15,32)}$, it had not been confirmed whether this group of bacteria contributes to the degradation of $3 \mathrm{CB}$ in the soil environment. Our results suggest that several Burkholderia strains actually function as effective 3CBdegraders in soil.

We employed not only $16 \mathrm{~S}$ rRNA gene but also a functional gene, benA, as a molecular marker. This gene encodes the alpha-subunit of benzoate 1,2-dioxygenase which is necessary for the conversion of $3 \mathrm{CB}$ to 3 -chlorocatechol ${ }^{33)}$. It has been reported that this gene is essential for 3CB-degradation in Burkholderia xenovorans LB4005). On the other hand, some 3CB-degrading bacteria (e.g. Alcaligenes sp. L6) do not use a metabolic pathway involving 3-chlorocatechol but use a pathway involving gentisate or protocatechuate as the intermediate $^{19,28)}$. The PCR-DGGE of benA was thought to be inadequate to detect this type of 3CB-degrader. This time, however, the PCR-DGGE of benA could detect the greater part of the enriched populations that were detected in the profiles of $16 \mathrm{~S}$ rRNA genes. These results suggested that the bacteria using a pathway involving 3-chlorocatechol were the major 3CB-degrading populations in the soil.

Several studies reported that bacteria introduced into a microbial community for bioaugmentation were hardly detected by PCR-DGGE ${ }^{2,3,22}$. In general, bacterial populations that make up $1 \%$ or more of the total target community can be detected by PCR-DGGE ${ }^{26}$. Thus, the difficulty in detection of the introduced bacteria probably suggests that the bacteria could not proliferate to such levels in the community. In our experiment, the initial density of the inoculated strains was calculated at about $10^{7}-10^{8}$ cells per gram of soil. Despite such a high population density, the intensity of DGGE bands corresponding to the strains was not so high immediately after the inoculation (day 0 ). Therefore, it is most likely that at least $10^{7}-10^{8}$ cells per gram of soil were required to detect the inoculated strains as the bands in the DGGE profiles of the soil. On the other hand, 3 days after the inoculation, five 3CB-degrading strains (ASS3, 7, 8, 11, and 14) came to be detected as prominent bands. These results suggested that the five strains could increase their populations to a level which largely exceeded their initial population densities. The DGGE profile of the co-inoculated soil showed that strains ASS8 and ASS14 intensified more quickly than the others. This result suggested that the five strains competed with each other to utilize $3 \mathrm{CB}$, and that ASS8 and ASS14 were superior to the other strains, at least at the point in time immediately after their introduction into the soil. This also seems to be one of the reasons for why bands corresponding to ASS8 and ASS14 appeared earlier than those of other strains in the DGGE profiles of the $3 \mathrm{CB}$ dosed soil.

It has been often shown that the results of bacterial community analyses based on culture-independent methods are not consistent with those based on culture-dependent methods ${ }^{9,10)}$. In contrast, in the present study, more than $90 \%$ of the isolates had the same sequences as any of those of the intensified bands in the DGGE profiles. This good correspondence between the isolates and the intensified bands might be because the repeated application of $3 \mathrm{CB}$ acted as a strong selective pressure, and because the soil extract agar was appropriate to detect the $3 \mathrm{CB}$-degrading bacteria.

It has been recognized that liquid enrichment has a significant bias in the isolation of pollutant degraders. Dunbar et $a .^{7)}$ assessed the diversity of 2,4-dichlorophenoxyacetatedegrading bacteria obtained from soil by direct plating and by liquid enrichment. They found that the diversity of the isolates obtained from liquid enrichment culture was significantly lower than that of the isolates obtained by direct plating. Watanabe et al. ${ }^{39)}$ identified dominant phenol-degrading bacteria in activated sludge using PCR-TGGE and reported that the dominant populations could not be isolated from liquid enrichment cultures. Also in our study, the PCR-DGGE analyses revealed that liquid enrichment selectively concentrated only a small proportion of the 3CB-degrading bacteria in the soil. Strains ASS8 and ASS14, which accumulated in the 3CB-dosed soil but disappeared in the liquid enrichment culture, showed good 3CB-degrading ability and especially good adaptability to the soil. For the bioaugmentation of polluted sites, it is essential that the introduced bacteria adapt smoothly to the environment and degrade the pollutant effectively under the expected conditions. Our results clearly illustrated that such bacteria were missed throughout the liquid enrichment process. In addition, the results showed that direct plating on soil extract agar is more suitable for isolating the degraders under environmental conditions.

One of the major advantages of using molecular community profiling such as PCR-DGGE for the study of pollutantdegrading bacteria is that the method enables one to understand their dynamics in the environment. Of course, because the method is strongly dependent on PCR, the resultant profile might be biased by several factors in the PCR, especially by primer design. Therefore, to draw more reliable conclusions, several primer sets should be used as in the present study. Our results suggest that a combination of PCR-DGGE and culture methods greatly helps in isolating useful bacteria capable of degrading a target pollutant effectively under the expected environmental conditions.

\section{Acknowledgements}

This work was supported by a grant-in-aid (Hazardous Chemicals) from the Ministry of Agriculture, Forestry, and Fisheries of Japan (HC-08-2323(1)-1), and in part by a grant-in-aid from the Ministry of Education, Culture, Sports, Science, and Technology of Japan.

\section{References}

1) Amann, R.I., W. Ludwig, and K.H. Schleifer. 1995. Phylogenetic identification and in situ detection of individual microbial cells without cultivation. Microbiol. Rev. 59:143-169.

2) Boon, N., J. Goris, P. De Vos, W. Verstraete, and E.M. Top. 2000. Bioaugmentation of activated sludge by an indigenous 3-chloroaniline-degrading Comamonas testosteroni strain, I2gfp. Appl. Environ. Microbiol. 66:2906-2913.

3) Boon, N., E.M. Top, W. Verstraete, and S.D. Siciliano. 2003. Bioaugmentation as a tool to protect the structure and function of an activated-sludge microbial community against a 3-chloroaniline shock load. Appl. Environ. Microbiol. 69:1511-1520.

4) Chatterjee, D.K., S.T. Kellogg, S. Hamada, and A.M. Chakrabarty. 1981. Plasmid specifying total degradation of 3-chlorobenzoate by a modified ortho pathway. J. Bacteriol. 146:639-646.

5) Denef, V.J., J.A. Klappenbach, M.A. Patrauchan, C. Florizone, J.L. Rodrigues, T.V. Tsoi, W. Verstraete, L.D. Eltis, and J.M. Tiedje. 
2006. Genetic and genomic insights into the role of benzoatecatabolic pathway redundancy in Burkholderia xenovorans LB400. Appl. Environ. Microbiol. 72:585-595.

6) Dorn, E., M. Hellwig, W. Reineke, and H.J. Knackmuss. 1974. Isolation and characterization of a 3-chlorobenzoate degrading pseudomonad. Arch. Microbiol. 99:61-70.

7) Dunbar, J., S. White, and L. Forney. 1997. Genetic diversity through the looking glass: Effect of enrichment bias. Appl. Environ. Microbiol. 63:1326-1331.

8) El Fantroussi, S., L. Verschuere, W. Verstraete, and E.M. Top. 1999 Effect of phenylurea herbicides on soil microbial communities estimated by analysis of $16 \mathrm{~S}$ rRNA gene fingerprints and communitylevel physiological profiles. Appl. Environ. Microbiol. 65:982-988.

9) Ellis, R.J., P. Morgan, A.J. Weightman, and J.C. Fry. 2003. Cultivation-dependent and -independent approaches for determining bacterial diversity in heavy-metal-contaminated soil. Appl. Environ. Microbiol. 69:3223-3230.

10) Felske, A., A. Wolterink, R. van Lis, W.M. de Vos, and A.D. Akkermans. 1999. Searching for predominant soil bacteria: $16 \mathrm{~S}$ rDNA cloning versus strain cultivation. FEMS Microbiol. Ecol. 30:137-145.

11) Focht, D.D. 1993. Microbial degradation of chlorinated biphenyls, p. 341-407. In J.M. Bollag, and G. Stotzky (ed.), Soil Biochemistry. vol. 8. NY: Marcel Dekker, Inc., New York.

12) Francisco, P., Jr., N. Ogawa, K. Suzuki, and K. Miyashita. 2001. The chlorobenzoate dioxygenase genes of Burkholderia sp. strain NK8 involved in the catabolism of chlorobenzoates. Microbiology 147:121-133.

13) Fulthorpe, R.R., A.N. Rhodes, and J.M. Tiedje. 1996. Pristine soils mineralize 3-chlorobenzoate and 2,4-dichlorophenoxyacetate via different microbial populations. Appl. Environ. Microbiol. 62:11591166.

14) Gentry, T.J., D.T. Newby, K.L. Josephson, and I.L. Pepper. 2001. Soil microbial population dynamics following bioaugmentation with a 3-chlorobenzoate-degrading bacterial culture. Bioaugmentation effects on soil microorganisms. Biodegradation 12:349-357.

15) Gentry, T.J., G. Wang, C. Rensing, and I.L. Pepper. 2004. Chlorobenzoate-degrading bacteria in similar pristine soils exhibit different community structures and population dynamics in response to anthropogenic 2-, 3-, and 4-chlorobenzoate levels. Microb. Ecol. 48:90-102.

16) Hernandez, B.S., F.K. Higson, R. Kondrat, and D.D. Focht. 1991. Metabolism of and inhibition by chlorobenzoates in Pseudomonas putida P111. Appl. Environ. Microbiol. 57:3361-3366.

17) Hoshino, Y.T., and N. Matsumoto. 2004. An improved DNA extraction method using skim milk from soils that strongly adsorb DNA. Microb. Environ. 19:13-19.

18) Huong, N.L., K. Itoh, and K. Suyama. 2008. 2,4-Dichlorophenoxyacetic acid (2,4-D)- and 2,4,5-trichlorophenoxyacetic acid (2,4,5-T)degrading bacterial community in soil-water suspension during the enrichment process. Microb. Environ. 23:142-148.

19) Krooneman, J., E.B. Wieringa, E.R. Moore, J. Gerritse, R.A. Prins, and J.C. Gottschal. 1996. Isolation of Alcaligenes sp. strain L6 at low oxygen concentrations and degradation of 3-chlorobenzoate via a pathway not involving (chloro)catechols. Appl. Environ. Microbiol. 62:2427-2434.

20) Krooneman, J., A.O. Sliekers, T.M. Pedro Gomes, L.J. Forney, and J.C. Gottschal. 2000. Characterization of 3-chlorobenzoate degrading aerobic bacteria isolated under various environmental conditions. FEMS Microbiol. Ecol. 32:53-59.

21) Lane, D.J., B. Pace, G.J. Olsen, D.A. Stahl, M.L. Sogin, and N.R. Pace. 1985. Rapid determination of 16S ribosomal RNA sequences for phylogenetic analyses. Proc. Natl. Acad. Sci. USA 82:6955-6959.

22) MacNaughton, S.J., J.R. Stephen, A.D. Venosa, G.A. Davis, Y.J. Chang, and D.C. White. 1999. Microbial population changes during bioremediation of an experimental oil spill. Appl. Environ. Microbiol. 65:3566-3574.

23) Macur, R.E., J.T. Wheeler, M.D. Burr, and W.P. Inskeep. 2007. Impacts of 2,4-D application on soil microbial community structure and on populations associated with 2,4-D degradation. Microbiol. Res. 162:37-45.

24) Miller, L.G., K.L. Warner, S.M. Baesman, and R.S. Oremland. 2004. Degradation of methyl bromide and methyl chloride in soil microcosms: Use of stable $\mathrm{C}$ isotope fractionation and stable isotope probing to identify reactions and the responsible microorganisms. Geochimica et Cosmochimica Acta 68:3271-3283.

25) Morimoto, S., K. Togami, N. Ogawa, A. Hasebe, and T. Fujii. 2005. Analysis of a bacterial community in 3-chlorobenzoate-contaminated soil by PCR-DGGE targeting the 16S rRNA gene and benzoate 1,2dioxygenase gene (benA). Microbes Environ. 20:151-159.

26) Muyzer, G., and K. Smalla. 1998. Application of denaturing gradient gel electrophoresis (DGGE) and temperature gradient gel electrophoresis (TGGE) in microbial ecology. Antonie Van Leeuwenhoek 73:127-141.

27) Muyzer, G. 1999. DGGE/TGGE a method for identifying genes from natural ecosystems. Curr. Opin. Microbiol. 2:317-322.

28) Nakatsu, C.H., and R.C. Wyndham. 1993. Cloning and expression of the transposable chlorobenzoate-3,4-dioxygenase genes of Alcaligenes sp. strain BR60. Appl. Environ. Microbiol. 59:3625-3633.

29) Ogawa, N., and K. Miyashita. 1995. Recombination of a 3-chlorobenzoate catabolic plasmid from Alcaligenes eutrophus NH9 mediated by direct repeat elements. Appl. Environ. Microbiol. 61:37883795.

30) Øvreas, L., L. Forney, F.L. Daae, and V. Torsvik. 1997. Distribution of bacterioplankton in meromictic Lake Saelenvannet, as determined by denaturing gradient gel electrophoresis of PCR-amplified gene fragments coding for 16S rRNA. Appl. Environ. Microbiol. 63:33673373.

31) Pavlu, L., J. Vosahlova, H. Klierova, M. Prouza, K. Demnerova, and V. Brenner. 1999. Characterization of chlorobenzoate degraders isolated from polychlorinated biphenyl-contaminated soil and sediment in the Czech Republic. J. Appl. Microbiol. 87:381-386.

32) Ramirez-Saad, H.C., A. Sessitsch, W.M. de Vos, and A.D. Akkermans. 2000. Bacterial community changes and enrichment of Burkholderia-like bacteria induced by chlorinated benzoates in a peat-forest soil-microcosm. Syst. Appl. Microbiol. 23:591-598.

33) Reineke, W., and H.J. Knackmuss. 1988. Microbial degradation of haloaromatics. Annu. Rev. Microbiol. 42:263-287.

34) Sørensen, S.R., J. Rasmussen, C.S. Jacobsen, O.S. Jacobsen, R.K. Juhler, and J. Aamand. 2005. Elucidating the key member of a linuron-mineralizing bacterial community by PCR and reverse transcription-PCR denaturing gradient gel electrophoresis 16S rRNA gene fingerprinting and cultivation. Appl. Environ. Microbiol. 71:41444148.

35) Tonso, N.L., V.G. Matheson, and W.E. Holben. 1995. Polyphasic characterization of a suite of bacterial isolates capable of degrading 2,4-D. Microb. Ecol. 30:3-24.

36) Torsvik, V., F.L. Daae, R.A. Sandaa, and L. Øvreas. 1998. Novel techniques for analysing microbial diversity in natural and perturbed environments. J. Biotechnol. 64:53-62.

37) Valle, A., G. Boschin, M. Negri, P. Abbruscato, C. Sorlini, A. D'Agostina, and E. Zanardini. 2006. The microbial degradation of azimsulfuron and its effect on the soil bacterial community. J. Appl. Microbiol. 101:443-452.

38) Vinas, M., J. Sabate, C. Guasp, J. Lalucat, and A.M. Solanas. 2005. Culture-dependent and -independent approaches establish the complexity of a PAH-degrading microbial consortium. Can. J. Microbiol. 51:897-909.

39) Watanabe, K., M. Teramoto, H. Futamata, and S. Harayama. 1998. Molecular detection, isolation, and physiological characterization of functionally dominant phenol-degrading bacteria in activated sludge. Appl. Environ. Microbiol. 64:4396-4402.

40) Wilson, K. 1990. Preparation of genomic DNA from bacteria, p. 2.4.1-2.4.2. In F.M. Ausubel, R. Brent, R.E. Kingston, D.D. Moore, J.G. Seidman, J.A. Smith, and K. Struhl (ed.), Current Protocols in Molecular Biology, vol. 1. John Wiley \& Sons, New York. 